\title{
Depot-medroxy progesterone acetate as an effective contraception method in lactating mothers
}

\author{
Vijaya Monish Babre*, Jyaneshwari Ashok Phadke
}

Family Planning Association of India, Kutumb Sudhar Kendra, Mumbai, Maharashtra, India

Received: 08 July 2016

Revised: 13 September 2016

Accepted: 14 September 2016

\section{*Correspondence:}

Dr. Vijaya M. Babre,

E-mail: drvbabre@gmail.com

Copyright: () the author(s), publisher and licensee Medip Academy. This is an open-access article distributed under the terms of the Creative Commons Attribution Non-Commercial License, which permits unrestricted non-commercial use, distribution, and reproduction in any medium, provided the original work is properly cited.

\begin{abstract}
Background: Contraception is the deliberate use of artificial methods or other techniques to prevent pregnancy as a consequence of sexual intercourse. Depot medroxy progesterone (DMPA) injection $150 \mathrm{mg}$ intramuscular was used for contraception in this study, once every 3 months \pm 14 days. The objective was to establish safety and effectiveness of DMPA in lactating and non-lactating mothers, observe side effects related to usage of DMPA and also establish its effectiveness as contraception method.

Methods: This is retrospective study performed at Family Planning Association of India's Kutumb Sudhar Kendra. Mumbai Central.

Result: Patients who had received first dose at 6 weeks of postpartum period and those who received between 6 weeks to one year showed lactation in $84.16 \%$ and non-lactation in $15.84 \% .28 .71 \%$ lactating patients had taken injection at 6 weeks of post-partum period and $71.29 \%$ had taken between 6 weeks to 1 year. Lactating patients who had taken injection at 6 weeks and continued DMPA for more than 4 injections were $48.27 \%$. 36.84\% non-lactating patients had continued for more than 4 injections. This signifies that acceptance and continuation rate of DMPA is more in lactating patients than in non-lactating patients.

Conclusions: DMPA is an effective method of contraception in lactating mothers; proper counseling will increase awareness and acceptance of DMPA in lactating mothers.
\end{abstract}

Keywords: Injection DMPA, Contraceptive method, Lactating mother

\section{INTRODUCTION}

India's population by year 2050 is projected to reach 1.53 billion, making it the most populated country in the world. A very poor usage of contraception by Indian women and ignorance in this matter has to be changed. Injection DMPA is an effective contraceptive method in lactating mother. ${ }^{1,2}$

As per NFHS, the contraception prevalence among the different states and unmet need for family planning is at $7.6 \%$ and $2.9 \%$ for spacing. Contraception should become a peoples movement rather than be forced upon the people. Family planning should come to mean "few babies-but better babies".,4

\section{Aim and objective}

- To establish safety and effectiveness of injection DMPA in lactating and non-lactating women.

- To study acceptance rate of injection DMPA in lactating mothers who had received first dose at 6 weeks of postpartum period than those received between 6 weeks to one year.

- To study the continuation rate as a contraception for more than a year in a lactating and non-lactating patients.

- To study side effects of injection DMPA.

- To study effectiveness of injection DMPA as contraceptive method. 


\section{METHODS}

This is retrospective study performed at Family Planning Association of India's Kutumb Sudhar Kendra, Mumbai Central, India from 1 January 2009 to 31 December 2010. Total number of patients in study group were 120 .

\section{Inclusive criteria}

- Age: $22-35$ years.

- Lactating women: Group 1: First dose of injection DMPA at 6 weeks. Group 2: First dose of injection DMPA 6 weeks to 1 year.

- Non lactating women

- Weight: 45-65 kg.

- Low risk patients

\section{Exclusive criteria}

- Age: More than 35 years.

- High risk patients: Medical diseases like hypertension, diabetes mellitus, obesity, hemoglobinopathies, liver disease etc.

Injection was used depot Medroxy progesterone (DMPA) $150 \mathrm{mg}$.

Mode of administration: Deep intramuscular (on buttocks) every 3 monthly. ${ }^{1,2}$

\section{Group of patients}

- First dose at 6 weeks of post-partum period.

- First dose between 6 weeks to 1 year of delivery.

- First dose in non-lactating women between 5-7 days of LMP (last menstrual period).

\section{RESULTS}

- Weight gain (more than $3 \mathrm{~kg}$ ): $11(9.17 \%)$.

- Complain of irregular bleeding and spotting per vaginum: $22(18.34 \%)$.

- Menorrhagia: 01(0.8\%).

- Failure rate: Not a single client has become pregnant during study period.

\section{DISCUSSION}

In present study of 120 patients, $84.16 \%$ were lactating and $15.84 \%$ were non-lactating women. Lactating patients who had taken injection at 6 weeks had continued injection DMPA for more than 4 injections were $48.27 \%$. Lactating patients between 6 weeks to one year who had continued for more than 4 injections were $16.67 \%$ (Table 1). This shows that's there is good acceptance and continuation rate in the patients who had taken first dose of injection DMPA at 6 weeks of postpartum period against those who had taken injection DMPA between 6 weeks to one year.

Table 1: Lactating patients between 6 weeks to one year having more than 4 injections.

\begin{tabular}{|ll|llll|} 
Group of client & $\begin{array}{l}1^{\text {st }} \text { Dose of } \\
\text { DMPA after } \\
\text { 6 weeks }\end{array}$ & $\begin{array}{l}1^{\text {st }} \text { Dose DMPA } \\
\text { between } 6 \text { weeks } \\
\text { to } 1 \text { Year }\end{array}$ & $\begin{array}{l}1^{\text {st }} \text { Dose of DMPA at } \\
6 \text { weeks who had } \\
\text { More than } 4\end{array}$ & $\begin{array}{l}1^{\text {st }} \text { Dose of DMPA } \\
\text { injections }\end{array}$ & $\begin{array}{l}\text { ateeks to } 1 \\
\text { year more than } 4 \\
\text { injections }\end{array}$ \\
\hline Lactating clients & $101(84.16 \%)$ & $29(28.17 \%)$ & $72(71.29 \%)$ & $14(48.27 \%)$ & $12(16.67 \%)$ \\
\hline
\end{tabular}

Table 2: Injection DMPA more than 4 doses.

\begin{tabular}{|lll|}
$\begin{array}{l}\text { Group of } \\
\text { client }\end{array}$ & Number & $\begin{array}{l}\text { Injection DMPA } \\
\text { who had more } \\
\text { than } 4 \text { doses }\end{array}$ \\
\hline $\begin{array}{l}\text { Non-Lactating } \\
\text { clients }\end{array}$ & $\begin{array}{l}19 \\
(15.84 \%)\end{array}$ & $\begin{array}{l}07 \\
(36.84 \%)\end{array}$ \\
\hline
\end{tabular}

Non-lactating patients who had continued more than 4 injections were $36.84 \%$ (Table 2). This signifies that acceptance and continuation rate of injection DMPA is more in lactating patients than in non-lactating patients.

Menstrual complaints like irregular bleeding, menorrhagia are more common in non-lactating group than in lactating mothers. No estrogen contraindication or side effects are related with injection DMPA. Amenorrhea with long term use of DMPA will be helpful for working women, athletes, patients with anemia and mentally challenged women. It also reduces incidence of painful sickle cell crises, decreases risk of endometrial and epithelial ovarian cancer. ${ }^{3}$ Thick cervical mucus and amenorrhea limits incidence of pelvic inflammatory diseases. Injection DMPA is also used to treat decreased risk of endometrial cancer. ${ }^{6}$ Depo-provera reduces the risk of endometrial cancer by $80 \% .^{4,5,7}$ The reduced risk of endometrial cancer in depo-provera users is thought to be due to both the direct anti-proliferative effect of progestogen on the endometrium and the indirect reduction of estrogen levels by suppression of ovarian follicular development. ${ }^{5}$ Decreases risk of iron deficiency anemia, pelvic inflammatory disease (PID), ectopic pregnancy and uterine fibroids, decreases symptoms of endometriosis. 8,9 Decreases incidence of primary dysmenorrhea, ovulation pain and functional ovarian cysts. Decreases incidence of seizures in women with epilepsy. Additionally, unlike most other hormonal contraceptives. Depo-Provera's contraceptive 
effectiveness is not affected by enzyme-inducing antiepileptic drugs. ${ }^{10}$ Decreases incidence and severity of sickle cell crises in women with sickle-cell disease. ${ }^{8}$

A proper antenatal counseling of women about injection DMPA will increase the acceptance and efficacy. It can be incorporated as a National Family Planning Program.

\section{CONCLUSION}

There is good acceptance of injection DMPA as contraceptive in lactating as non-lactating patients. Continuation rate is better in patients who had first dose of injection DMPA at 6 weeks of postpartum period.

There were no significant side effects, injection DMPA is an effective method of contraception with no failure rate as observed in the current study.

Funding: No funding sources

Conflict of interest: None declared

Ethical approval: Not required

\section{REFERENCES}

1. Family planning Queenland. Available at https://en.wikipedia.org/wiki/Family_Planning_Quee nsland. Accessed on 3 February 2011.

2. Chaudhri SK and International Contributors. Practice of Fertility Control: A Comprehensive Textbook. 4th edition, 2000.
3. Sengupta J. Accessing modern contraceptive technologies in India. Indian J Physiol Pharmacol. 2006;50(4):327-40.

4. Kaunitz AM. Current options for injectable contraception in the United States. Semin Reprod Med. 2001;19(4):331-7.

5. Bigrigg A, Evans M, Gbolade B, Newton J, Pollard L, Szarewski A, et al. Depo provera position paper on clinical use, effectiveness and side effects. Br J Fam Plann. 1999;25(2):69-76.

6. WHO collaborative study of neoplasia and steroid contraceptives. Depot-medroxy progesterone acetate (DMPA) and risk of endometrial cancer. Int $\mathrm{J}$ Cancer. 1999;49(2):186-90.

7. Santen, Richard J. Endocrinology of breast and endometrial cancer. In Strauss, Jerome F. Barbieri, Robert L. Yen and Jaffe's Reproductive Endocrinology. $5^{\text {th }}$ edition; Philadelphia:Elsevier Saunders. 2004:787-809.

8. Westhoff C. Depot-medroxyprogesterone acetate injection (depot-provera): a highly effective contraceptive option with proven long-term safely. Contraception. 2003;68(2):75-87.

9. Leon S, Darney Philip D. Injectable contraception. In: Speroff Leon, Darney Philip D, eds. A Clinical Guide for Contraception. 4th ed. Philadelphia: Lippincott Williams and Wilkins; 2005: 201-220.

10. Obrien MD, Guillebaud J. Contraception for women with epilepsy. Epilepsia. 2006;47(9):1419-22.

Cite this article as: Babre VM, Phadke JA. Depotmedroxy progesterone acetate as an effective contraception method in lactating mothers. Int $\mathrm{J}$ Reprod Contracept Obstet Gynecol 2016;5:3422-4. 